\title{
Tetralogy of Fallot with haemangioma of the upper extremity in a child with biventricular failure: a diagnostic conundrum
}

\author{
Mansi Verma (1) , 'Vineeta Ojha 다, 'Sanjeev Kumar, ${ }^{1}$ Sivasubrmanian Ramakrishnan²
}

'Department of Cardiovascular Radiology and Endovascular Interventions, All India Institute of Medical Sciences, New Delhi, India

${ }^{2}$ Cardiology, All India Institute of Medical Sciences, New Delhi, Delhi, India

Correspondence to Dr Sanjeev Kumar; sanjeevradio@gmail.com

Accepted 28 October 2021
Check for updates

(C) BMJ Publishing Group Limited 2021. No commercial re-use. See rights and permissions. Published by BMJ.

To cite: Verma M, Ojha $V$, Kumar $\mathrm{S}$, et al. BMJ Case Rep 2021;14:e247195. doi:10.1136/bcr-2021247195

\section{DESCRIPTION}

A 17-year-old male child diagnosed with tetralogy of Fallot presented with worsening dyspnoea over a course of 2 years. Transthoracic echocardiography (TTE) revealed severe biventricular dysfunction (left and right ventricular ejection fractions of $15 \%$ and 20\%, respectively). TTE, done 2 years earlier, had shown normal biventricular ejection fraction. The child also had a soft tissue swelling on the right arm since childhood which had increased over the last 2 years. On examination, the soft tissue swelling was warm to palpate with no thrill, redness or tenderness. In view of the clinical suspicion of a vascular malformation and the recent onset of severe left ventricular dysfunction, it was crucial to characterise this lesion to rule out any significant shunting causing high output cardiac failure.

The radiograph of the right arm depicted bony expansion and multiple lytic lesions with sclerotic rim involving distal humerus (Figure 1). Doppler ultrasonography revealed a soft tissue mass in distal part of the arm with arterial feeders demonstrating high resistance triphasic wave form and the draining veins showing monophasic flow. The draining veins showed thrombus at places (Figure 2). Further, time resolved magnetic resonance angiography revealed multiple dilated vascular channels in distal part of arm and elbow involving the intramuscular and intermuscular planes with multiple arterial feeders from the hypertrophied brachial artery seen supplying the soft tissue mass. However, there was no early filling

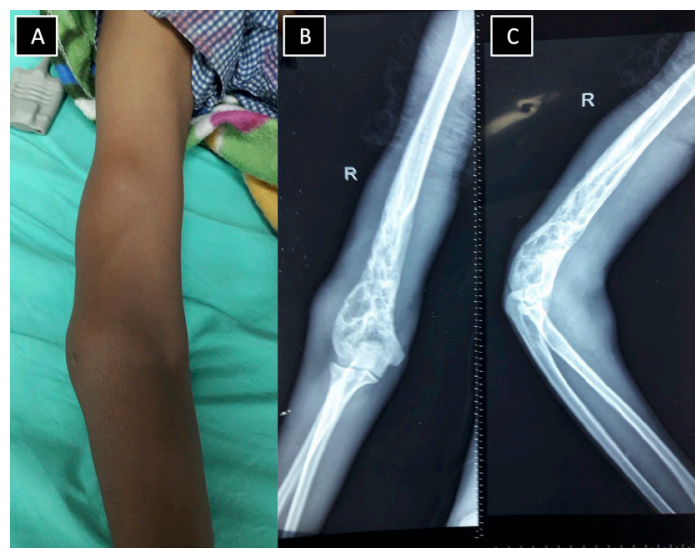

Figure 1 Clinical photograph (A) depicting soft tissue swelling in the distal arm and around elbow joint. Anteroposterior (B) and lateral radiograph (C) showing bony expansion and multiple lytic lesions with sclerotic rim in the distal part of humerus.

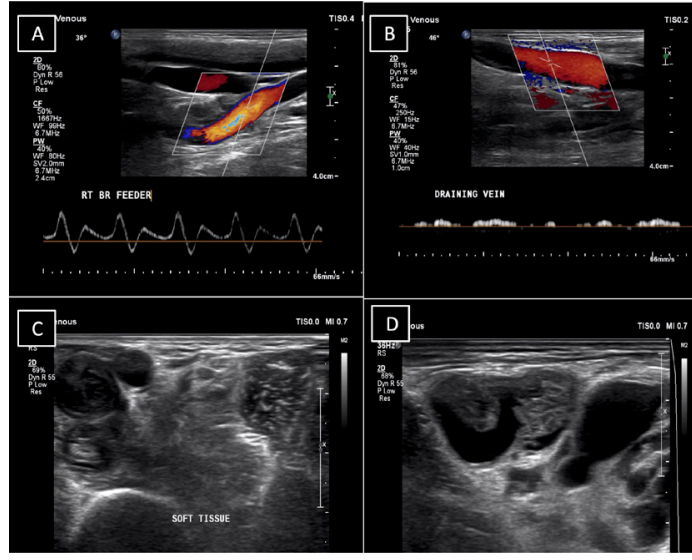

Figure 2 Doppler ultrasound demonstrating triphasic flow in the arterial feeders (A) with monophasic flow in draining veins (B). Gray scale ultrasound showing large soft tissue component (C) with thrombus in venous channels (D).

of draining veins which showed normal calibre. Hence, in the presence of a well demarcated soft tissue mass and lack of arterialisation of draining veins, the diagnosis of non-involuting haemangioma was made. Cardiac magnetic resonance, done to rule out myocarditis as a cause of severe left ventricular dysfunction, did not reveal any specific aetiology. As the clinical suspicion of a vascular lesion causing significant shunting was high, digital subtraction angiography was done to confirm the

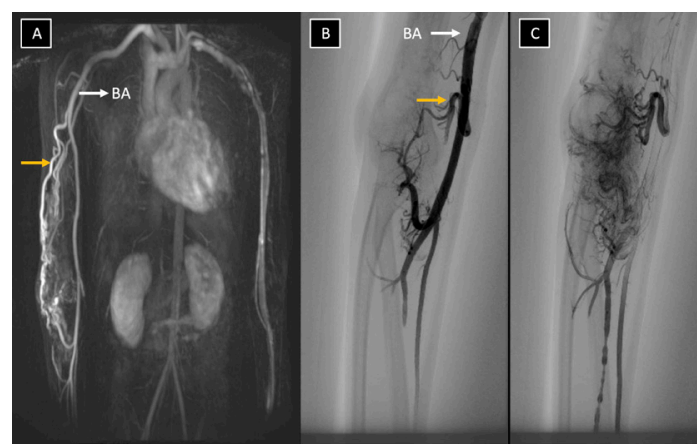

Figure 3 Time resolved magnetic resonance angiography $(A)$ showing multiple arterial feeders (depicted by yellow arrow) from brachial artery (BA) with no early filling of draining veins. Digital subtraction angiography $(\mathrm{B}-\mathrm{C})$ depicting arterial channels from brachial artery (yellow arrow) and soft tissue blush with no early draining vein. 
diagnosis. It revealed soft tissue blush with multiple arterial feeders, however no early filling of draining veins was observed thus establishing the diagnosis of haemangioma (Figure 3). In addition, in view of biventricular dysfunction the various tested laboratory parameters (ferritin, transferrin, Hemoglobin A1C, thyroid levels, calcium) were normal. The child was considered for shunt or corrective surgery but the same was deferred in view of severe biventricular dysfunction and associated high risk. The dietary sodium was restricted to $<2 \mathrm{~g} /$ day and the fluid intake was limited to $<2 \mathrm{~L} /$ day. The child was administered weightadjusted ACE inhibitor, beta blocker and diuretics. After medical stabilisation and decongestion, the child was discharged in a clinically improved condition.

The International Society for the Study of Vascular Anomalies (ISSVA) classification represents an appropriate scheme to stratify proliferative vascular lesions into vascular tumours and vascular malformations. ${ }^{1}$ Multimodality imaging can lead to appropriate classification of these vascular anomalies. The presence of arterial flow can be present in both a haemangioma as well as high flow vascular malformation. However, the vascular tumours as haemangiomas are clearly demarcated and the arterialisation of draining vein is rare. ${ }^{2}$ The presence of soft tissue mass also occurs more commonly in a haemangioma. Arteriovenous malformations usually have low resistance high diastolic arterial flow with pulsatile flow in large draining veins. ${ }^{3}$ High

\section{Learning points}

- In presence of intracardiac disease, the presence of extracardiac high flow vascular anomaly can be a confounding factor in determining the cause of cardiac failure.

- Multimodality imaging can lead to appropriate classification of vascular anomalies.

- Vascular tumours as haemangiomas are clearly demarcated and the arterialisation of draining vein is rare. flow shunting occurring through large vascular malformations can lead to chronic volume overload of the heart and congestive heart failure of variable intensity. ${ }^{4}$ The degree of shunting determines the severity of cardiac failure. In childhood, the arteriovenous fistulas with associated cardiac manifestation most commonly involve cerebral or hepatic circulation. ${ }^{4}$ Extremity arteriovenous malformations rarely cause high output heart failure. ${ }^{5}$ This case highlights that in presence of intracardiac disease, the presence of extracardiac high flow vascular anomaly can be confounding factor in determining the cause of cardiac failure. Hence, multimodality imaging plays an important role to characterise these vascular anomalies and assess their haemodynamic significance.

Contributors MV and VO_data collection and manuscript preparation. SKmanuscript proofreading and validation. SR-manuscript editing.

Funding The authors have not declared a specific grant for this research from any funding agency in the public, commercial or not-for-profit sectors.

Competing interests None declared.

Patient consent for publication Consent obtained directly from patient(s).

Provenance and peer review Not commissioned; externally peer reviewed.

Case reports provide a valuable learning resource for the scientific community and can indicate areas of interest for future research. They should not be used in isolation to guide treatment choices or public health policy.

\section{ORCID iDs}

Mansi Verma http://orcid.org/0000-0002-3313-4350

Vineeta Ojha http://orcid.org/0000-0003-4371-5615

\section{REFERENCES}

1 Wildgruber M, Sadick M, Müller-Wille R, et al. Vascular tumors in infants and adolescents. Insights Imaging 2019;10:30.

2 Nozaki T, Nosaka S, Miyazaki 0, et al. Syndromes associated with vascular tumors and malformations: a pictorial review. Radiographics 2013;33:175-95.

3 Donnelly LF, Adams DM, Bisset GS. Vascular malformations and hemangiomas: a practical approach in a multidisciplinary clinic. AJR Am J Roentgenol 2000:174:597-608

4 Durand $\mathrm{P}$, Lambert V, Ozanne A. Extracardiac arteriovenous and venovenous malformations. In: Da Cruz E, Ivy D, Jaggers J, eds. Pediatric and congenital cardiology, cardiac surgery and intensive care. London: Springer, 2014.

5 Webb JB, O'Brien M, John PR, et al. Early presentation of an extremity arteriovenous malformation. Br J Plast Surg 2004;57:785-8.

Copyright 2021 BMJ Publishing Group. All rights reserved. For permission to reuse any of this content visit

https://www.bmj.com/company/products-services/rights-and-licensing/permissions/

BMJ Case Report Fellows may re-use this article for personal use and teaching without any further permission.

Become a Fellow of BMJ Case Reports today and you can:

- Submit as many cases as you like

- Enjoy fast sympathetic peer review and rapid publication of accepted articles

- Access all the published articles

Re-use any of the published material for personal use and teaching without further permission

Customer Service

If you have any further queries about your subscription, please contact our customer services team on +44 (0) 2071111105 or via email at support@bmj.com.

Visit casereports.bmj.com for more articles like this and to become a Fellow 